\title{
Hot-wired media
}

Papua New Guinea's two daily newspapers are leading the way in the response of the South Pacific news media to the challenge of cyberspace. Both websites came of age during the Sandline mercenary crisis, underscoring the value of content on the Internet.

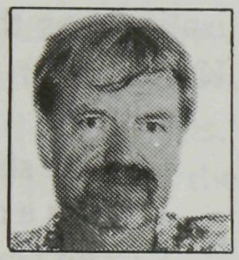

\section{By DAVID ROBIE}

IN TONGA, the Pacific kingdom whose major export is a variety of squash pumpkin adored in Japan, a major unspoiled resource is being exploitedInternet names. ${ }^{1}$ With almost a million domain names registered in the United States address of .com, Tonga is appealing because most good names are still available. Many of the names are for media organisations.

IN VANUATU, another Pacific latecomer to the computer world, the regional news cooperative Pacnews has begun distributing its service to many clients by email via the Internet. ${ }^{2}$ The service goes out three times a day to clients ranging from small circulation dailies such as the Cook Islands News and national radio stations such as the National Broadcasting Corporation to global wire services such as Agence France-Presse.

TINY publications throughout the Pacific have online editions, some updated rather sporadically. Even Rabi Online has news of sorts, although headline news of the week might only be an item about a routine visit of the administrator. $^{3}$

ALTHOUGH the phenomenal growth of the Internet has left the Pacific floundering in its wake, the news media has responded to the challenges of cyberspace in remarkably innovative ways. The Tonga Chronicle and Uni Tavur were among the earlier pioneers with online sites in $1995 .{ }^{4}$

Nowhere has this development been as dramatic as in Papua New Guinea where both national daily newspapers have launched online editions which have gained high profiles internationally, especially during the Sandline mercenary crisis and its aftermath. 


\section{DAVID ROBIE}

In the process, both web sites have opened an instant positive window to the world on Papua New Guinea, its social development, culture, and sociopolitical issues in a manner that was inconceivable in the days of the print editions and surface mail library copies. They have been doing far more for the country's contribution to information than the gaggle of tourist and chat sites offered by mainly offshore providers. This contrasts with the peek-a-boo world of modern electronic media and media globalisation - or rather 'gobbleisation's as the Asia-Pacific regional director of Inter Press News service, Kunda Dixit, describes it. He says:

As it shrouds the world in a fog of uniformity, television's globalness casts a dark shadow over fragile cultures that cling to the edge of time. This new global civilisation as propagated by flash multinational broadcasting is a juggernaut tearing through diversity, squishing [indigenous] wisdom into a flattened grey mass.

Information, or what editors in newsrooms in Atlanta or London decide is worthwhile for the world to know, is mixed up with amusement to be beamed to all corners of the globe. This is not just the "end of history", it is the end of geography. No place is too near or too far. Distance disappears, and if the line between real and unreal gets blurred, the defect is not on your set.

When you can switch from genocide in Rwanda to Natural Born Killers on $\mathrm{HBO}$ at the flick of a remote, where does voyeurism end and escapism begin? The bluish aura of the cathode rays have hypnotised the world into a consumerist, free market, materialistic trance. ${ }^{6}$

'Infotainment' is a commodity. News today has to sell, otherwise it is not news. However, the Internet and its interactivity have now posed a dramatic challenge to modern newsgathering methods. The Internet provides an infrastructure which enables communications and information services to be used by potentially millions of individuals and organisations around the globe. This bewildering network of computers, which has no centre of control, makes possible the exchange of ideas and information in a manner not possible via traditional electronic and print media.

I do not share the pessimistic and bureaucratic control view that some hold in Papua New Guinea who have little appreciation of its liberating potential. In traditional media, of course, the functions carried out by the content provider, the broadcaster or publisher and the audience tried to be relatively fixed, domestically based and highly regulated - at least in the case of broadcasting

In contrast, the functions carried out by participants in the online environment are more fluid and involve many participants from all over the world. The 
flood of email letters from many countries to The National after it went online in August last year is an example of this.

The characteristics of the Internet give it enormous potential for enhancing human communication and interaction, both domestically and internationally. The dramatic growth of international communication for our journalism students since we provided an email opportunity for them at the beginning of last year gives testimony to this.

According to the Editor and Publisher's Online Newspaper Database, there are now 1818 newspapers listed and the number of newspapers on the Internet's World Wide Web is currently 1733 - an increase of 95 in the past three months. Papua New Guinea has its daily national press 100 per cent on line with the national weekly The Independent keen to follow their lead.

\section{Freedom of speech and expression}

In terms of freedom of speech, the Internet offers its users an unprecedented opportunity to communicate and express themselves in a variety of ways. At its basic level, it enables people to send and receive email to and from anywhere in the world, and participate in real time conversations such as the PNG Online chat relay. It allows you to participate in a newsgroup with people who share your own interests or set up your own home page and entice people from all around the world to it by providing a venue for a stimulating topic of discussion, images, radio or increasingly video.

Thus it is not surprising that many journalists and members of the community see the Internet as the most free and democratic form of mass communication yet devised. In fact, the US District Court of Pennsylvania said of the Internet:

It is no exaggeration to conclude that the Internet has achieved, and continues to achieve, the most participatory marketplace of mass speech the world has ever seen. ${ }^{8}$

\section{Communicating with an international audience}

Internet just does not give media and community users the opportunity to express themselves on line. It also gives them a potential audience of millions of people around the globe. The National claims 91,00 'hits' a month for its web site; the Post-Courier about 100,000 a month. ${ }^{9}$ It is uncertain on what basis these claims are made.

I suspect that The National would be actually ahead given that its web site has been established far longer and that it quickly gained a reputation for reliability which was not initially matched by the Post-Courier. 


\section{DAVID ROBIE}

However, the Post-Courier has the advantage of its close links with the mega-News Corporation site of its parent company on the Internet. It has also made a commitment to be an 'indigenous' website rather than relying on Australian Internet service providers (ISP) and has involved its Papua New Guinean staff.

Nevertheless it is interesting to contrast the growth phenomena with the hard copy circulation figures of both newspapers - far more reliable statistics given that both papers are audited by the Audit Bureau of Circulations ( $A B C$ ). The National claims to be the 'fastest growing newspaper in the country' with paid daily average sales of 23,461 copies. ${ }^{10}$ The Post-Courier has 33,521 (Dec 96), down from its peak of around 41,000 in 1993, the year that The National was launched.

Unlike other forms of mass media, there are relatively low barriers to entry for both speakers and recipients in the online context. The basic requirements are a computer, a modem and a quality telephone line. With this basic equipment, roughly the cost of a stereo television set, and a flair for cyberspace design, a journalist - or any community person or group - can potentially produce a web site comparable to the Sydney Morning Herald, one of Australia's leading daily newspapers with a circulation of more than a quarter million.

Of course, the individual journalist's web site may not have the resources of the corporate site of Murdoch's News Corp or the Australian Broadcasting Corporation. But he or she would enjoy the same relative level of influence if they have quality content. In the razzmatazz world of Internet with so much gimmickry and garbage on line, quality content is still the key. And this is where news media practitioners will have the edge in the long run.

\section{Diversity on line}

Another potentially liberating characteristic of the Internet is its astounding diversity of content. This is because there are potentially as many sources of content as there online users - all contributing their thoughts, views, news and designs to cyberspace. Currently, one search engine alone can access some 30 million web pages. It can also give a user access to some four million articles on 15,000 newsgroups - all of which are constantly changing."

A year ago, Yahoo!, one of the major search engines, listed just one site under Papua New Guinea - Journalism Studies at UPNG, but this was on a hosted site at the University of Technology Sydney.

As one of the pioneers in Internet technology in the South Pacific, Journalism UPNG's own webserver officially went on line in August 1997 during an AusAID Media Training Project course with the theme Editing and the Net: http://journ.upng.ac.pg Or rather it was on Intranet temporarily while 
awaiting Papua New Guinea's Telikom to solve communications hitches through its antiquated Gerehu telephone exchange near the university.

To emphasise diversity, the Journalism UPNG server already hosts five web sites - Journalism UPNG itself; Papua New Guinea Nius http:// www.pactok.net.au/docs/nius/; Uni Tavur Online http://journ.upng.ac.pg/ UniTavur/UniT_index.html; Pacific Media Watch http://www.pactok.net.au/ docs/pmw/; Pacific Journalism Review http://journ.upng.ac.pg/PJR; and Café Pacific http://journ.upng.ac.pg/cafepacific. (Incidentally, this is the university's only current server - the university does not yet have; an official institutional home page as does the University of the South Pacific in Fiji).

In addition, Journalism UPNG also hosts 13 individual web sites for participants who took part in the Editing and the Net course. Some of these could be prototype web sites for media organisations such as The Independent, NauFM and EM TV. Print production courses at UPNG have been rewritten as multimedia courses although Papua New Guinca only came on line for Internet in May 1997.

The National http://www.wr.com.au/national set the trend in Papua New Guinea when it launched its web site on 5 August 1997, with a 'delightfully simple but user-friendly design [offering] home news, editorial (and even letters to the editor), business, sport and a back issue archive'.

On the day I checked for this review, the big news was Foreign Affairs Secretary Gabriel Dusava being referred to the Leadership Tribunal for an inquiry into alleged misconduct in office, and the aftermath of the temporary gagging of the Ombudsman's report on the Port Moresby water scandal. ${ }^{12}$

The web site, the first daily news one in the region, was the innovative brainchild of the general manager, S.F. Yong. A cyberspace buff and enthused by the lively web site of his old paper in Malaysia, The Star, he was convinced it could be done in Papua New Guinea too. ${ }^{13}$ Every day he and a senior systems executive colleague wade through the paper, converting files into html format and gaining enormous international goodwill for the paper as a result.

A month later, the rival Post-Courier had an impressive launch of its own web site which was touted as a big breakthrough for the region. However, readers eagerly awaiting news were disappointed with first the difficulty of connections and then finding only a News Corp advertising site with a stock editorial PR page about Papua New Guinea.

But on 22 December 1996, the Post-Courier http://www.datec.com.pg/ postcour/postcour.nsf launched its own impressive editorial site with its 


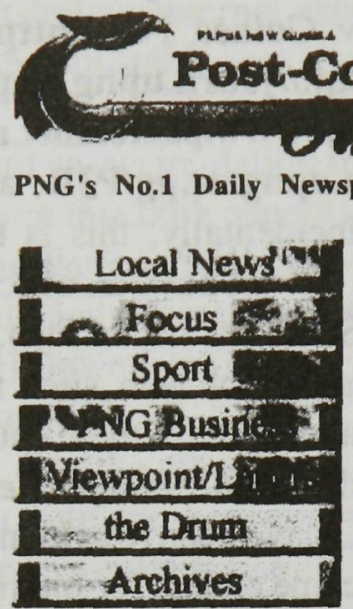

\section{??Search??}

Post-Courier Classifieds
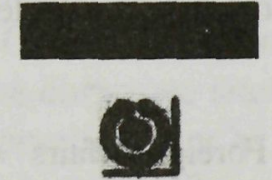

Access Post-Courier Classified through this external Service

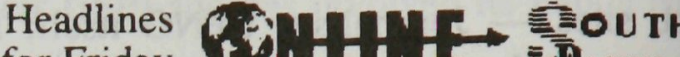 for Friday}

21 st of

Click here for the Intemet Experience

1997

Sandline 'kill' threat

Resistance force members were to be eliminated after Operation Oxster

- Minister looking at curbs on freedom

JUSTICE Minister Jacob Wama said yesterday he had "shelved" proposals for a Human Rights Commission and was looking at amending laws relating to freedom of movement next year in an effort to curb the increasing crime rate in the country.

- Magistrates resign over 'interference'

TWO magistrates on the Defence Force General Board of Inquiry resigned yesterday after it was disbanded.

- Police lock up soldier for firing weapon

A DEFENCE Force soldiers is now in the Buka police cells after indiscriminately firing off shots at Bonis Camp across the Buka Passage yesterday morning.

Calls for review of the govt's supply bills

OPPOSITION to the government's K800 million Supply Bills handed down on Tuesday is increasing, with calls for a review

for views/editorial letters send to: - postcourierQdntec.comegg

(c) Copyright 1997-Post-Courier and Datec Pty. Ltd. for technical support email us at Datec : techsupportedatecsom.pes

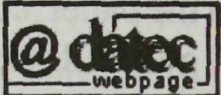

The Post-Courier Online ... ambitious and more graphics. 


\section{TATIONAL}

\section{O N I I N E}

Welcome to the homepage of Papua New Guinea's national newspaper

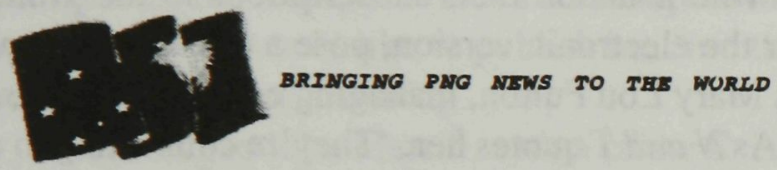

| $\underline{\text { Home }}$ | Opinion/Letters | Business | $\underline{\text { Sport | Back Issues | }}$

E-mail the Editor

Copyright 0 The National

PO Box 6817

Boroko NCD

Papua New Guinea

The National ... the pioneering, and most quoted, online daily newspaper in the Pacific.

distinctive bird of paradise logo. This site is more ambitious and comprehensive than The National's and has more graphics and includes appealing major features such as the Focus page. The Post-Courier's web site is largely prepared by the company's expatriate computer systems manager and the business editor who work on it part time with assistance from two other staff members, both Papua New Guinean. Training for national staff is expected to be a major component.

This has raised the stakes in the competition with The National which now has plans to revamp its own web site, employing four people including two journalists and a marketing person. This revamp is expected around October 1997.

While The National perhaps has the most quoted online newspaper by Papua New Guinea nationals and students abroad, its web site is largely inaccessible to staff journalists in the newsroom. This means little online research in the newsgathering process. The Post-Courier is more imaginative 


\section{DAVID ROBIE}

in its use of the Net for online searches, mainly in business journalism. But the newspaper also plans to have Internet linked computers in the newsroom for reporters to carry out online searches.

The quality weekly national newspaper, The Independent, and its sister paper Wantok are also considering having online editions. Journalism UPNG has been frequently asked for an email address for The Independent by readers keen to see the newspaper on line. (The paper's email: word@global.net.pg).

\section{Viability and the future of print}

What does all this mean for the traditional newspaper? As Newspapers and Technology asks, do readers who abandon their subscriptions to the printed newspaper, opting instead for the electronic version, pose a threat to newspapers? Not necessarily, argues Niary Lou Fulton, managing editor of the Washington Post's online edition. As $N$ and $T$ quotes her: 'They're connecting to us in a different way; we are still keeping them as customers. ${ }^{14}$ She continues:

Electronic media offers newspapers potential in terms of virtually limitless space, increased timeliness of stories and the ability to make the paper more interactive on the Web. They shouldn't necessarily be viewed as competition, but rather a way to offer readers more than the printed version is able. ${ }^{\text {is }}$

This is not an issue for the Papua New Guinea online media publishers at present. After all, only a tiny proportion of the population actually have Internet access. The online sites are reaching a new market, one that was neglected in the past - the expatriate Papua New Guinean and academics and others with a watching brief or interest in the country's development. But as Post-Courier general manager Max Tomlinson says, it is difficult to see the way ahead commercially for the websites:

Basically we are doing this for public relations, to build up the image of the newspaper and the services and news it has to offer. We are alert to the possibility of a commercial dimension to make it viable in the future. ${ }^{16}$

The newspaper signed up its first advertisement contract by email in midAugust as a spin-off from the web site involving a deal with a sawmilling operator from Kuwait. This was perhaps something of a positive breakthrough.

\section{The Net and the journalist}

In a sense, web sites are a vast series of interconnected niche markets. Maralyn Parker and Tanja Dreher cite Sarah Yeo on how "communication is no longer 
a one-way street' and point out how large, establishment newspapers such as the Sydney Morning Herald have yet to come to grips with this 'new, wonderfully creative but incredibly frightening concept'. ${ }^{17}$ This is good news for the small, independent electronic publisher prepared to be innovative and who seeks to provide quality information without being incimidated by the corporate media entities.

Thus the smaller papers in Papua New Guinea such as The Independent and Eastern Star face a creative challenge in following the dailies into creating web sites. But to ensure diversity in the country's media, it is to be hoped that the challenge is accepted and they add their authentic Papua New Guinean voice to cyberspace. And it also provides a challenge to individual Papua New Guinean journalists who would like to publish but find the economics of conventional print publishing too daunting.

According to John Merrill, author of the Existential Journalist, the coming generation of journalists can resign themselves to 'unruffled conformity and stability' working with mainstream media. ${ }^{18} \mathrm{Or}$, they can they can become hotwired, 'join the decimated ranks of existential journalists, reaffirm their selfhood, commit themselves to enlarging the frontiers of freedom and authenticity' and communicate on the Web.

\section{Notes:}

' Associated Press, quoted in the Post-Courier (1997). 'Tonga cashing in on Net name,' July 15.

2 Makin, Bob(1997), coordinator of the Pacific Isiands Broadcasting Association, communication to the writer, August 10.

${ }^{3}$ Robie, David (1996). 'Cyberspace, kava bowls and hot news in the Pacific', Pacific Journalism Review, 3:2, pp 191-194.

${ }^{4}$ Robie, David (1996). See 'The Internet and the South Pacific: A Development Case Study', PNG Collection, Michael Somare Library, Publication forthcoming.

5 Dixit, Kunda (1996). 'Un-western perspective on news', unpublished paper presented at the Asia-Pacific Media and Challenges conference in Sydney, November.

${ }^{6}$ Ibid.

7 Editor and Publisher(1997). 'Online Newspapers', http://www.mediainfo.com/ ephome/npaper/nphtm/online.htm, August 1.

8 Koomen, Kaaren (1996). 'Freedom of Speech and the Internet in Australia', unpublished paper presented at the Communicat:ons Law Centre Conference 'Free Speech in Australia', September 10.

The National (1997). 'The National alone records gain', August 22, p 1.

${ }_{10}$ Ibid.

11 Cited by Koomen.

12 Robie (1996), Pacific Journalism Review, 3:2: p 192. 


\section{DAVID ROBIE}

${ }^{13}$ Yong, S. F. (1997), general manager of The National, interview with writer, Augus! 19.

14 PANPA Bulletin, August 1997,

15 Ibid.

16 Tomlinson, Max (1997), general manager of the Post-Courier, telephone communication with the writer, August 28.

${ }^{17}$ Cited by Parker, Maralyn and Dreher, Tanja, unpublished 'Web Site Review of the Sydney Morning Herald Online', November 1996.

${ }_{18}$ Merrill, John C. Existential Journalism. Ames Iowa: Iowa State University Press, $1977 / 1996$.

David Robie is Lecturer in Journalism at the University of Papua New Guinea. He is also the creator of several World Wide Web sites, including Café Pacific. He presented this paper at the 1997 Waigani Seminar 'Information and the Nation', UPNG, 27-29 August 1997.

WWW: http://journ.upng.ac.pg/cafepacific - or http://acij.uts.edu.au cafepacific Email: drobie@pactok.peg.apc.org, or robied@upng.ac.pg

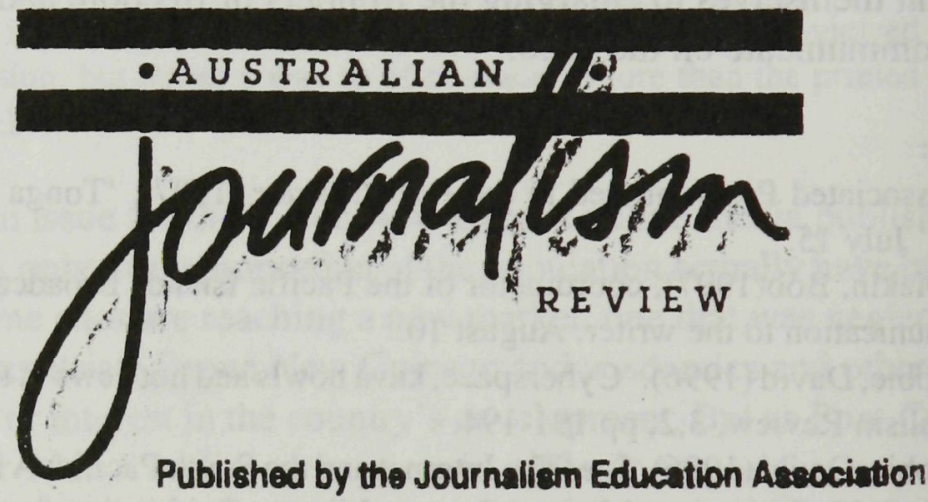

For subscriptions : vase contact:

Austidi in irurnatism Fieview Sutuerigians.

The Tieasurer, Ji-A.

Faculty' of Humanities,

University of Western Sydney, Nepean,

PO Rox 10,

Kingswood, NSV 2747. Australia.

Phorie: $\quad$ Martin Hirst (02) 96787363

Fax: $\quad$ (02) 96787399

Email: r.hirst@nepoan.u!vs.cdu.au

Please niake cheques payable to AUstralian uoumalism Review or JEA 